\title{
International trade of animal feed: its relationships with livestock density and $N$ and $P$ balances at country level
}

\author{
Jingmeng Wang • Qian Liu • Yong Hou • Wei Qin · Jan Peter Lesschen • \\ Fusuo Zhang $\cdot$ Oene Oenema
}

Received: 31 January 2017/Accepted: 4 October 2017/Published online: 4 November 2017

(C) The Author(s) 2017. This article is an open access publication

\begin{abstract}
International trade of food and feed has facilitated the specialization and agglomeration of agricultural production systems in many countries. Confined animals in specialized production systems are increasingly supplied with soybean and maize, imported from other countries. This has increased animal productivity but has also contributed to spatially decoupled crop and animal production systems. We analyzed the changes in the trade of soybean and maize at the global level in the period 1961-2011, and related these to the changes in livestock density and nutrient balances in the whole food system for 11 selected countries. Export of soybean and maize remained dominated by few countries (mainly USA,
\end{abstract}

Electronic supplementary material The online version of this article (doi:10.1007/s10705-017-9885-3) contains supplementary material, which is available to authorized users.

J. Wang · Q. Liu · W. Qin · O. Oenema

Department of Soil Quality, Wageningen University and

Research, P.O. Box 47, 6700 AA Wageningen,

The Netherlands

Y. Hou $\cdot$ F. Zhang $(\bowtie)$

Key Laboratory of Plant-Soil Interactions, MOE, College

of Resources and Environmental Sciences, China

Agricultural University, Beijing 100193, China

e-mail: zhangfs@cau.edu.cn

\section{J. P. Lesschen}

Wageningen Environmental Research, Wageningen

University and Research, P.O. Box 47,

6700 AA Wageningen, The Netherlands
Argentina and Brazil) during the period 1961-2011, while the number of importing countries increased. Increases in the import of maize and soybean are positively related with changes in livestock density and $\mathrm{N}$ and $\mathrm{P}$ balances of national food systems. Imported soybean accounted for $12-36 \%$ of the calculated $\mathrm{N}$ balance at country level, and imported maize for $0-26 \%$. There were large differences between importing countries; increases in the $\mathrm{N}$ surplus ranged from 75 to $306 \mathrm{~kg} \mathrm{~N} / \mathrm{ha}$ and in the $\mathrm{P}$ surplus from 2 to $49 \mathrm{~kg}$ P/ha when the mean livestock density increased $1 \mathrm{LU} / \mathrm{ha}$. This variation is related to differences in nutrient management regulations and to spatial variations in livestock density within countries. Our study contributes to the understanding of the complex relationships between the international trade of animal feed, livestock density and environmental impacts associated with $\mathrm{N}$ and $\mathrm{P}$ balances.

Keywords Food system - Nutrient balances · Specialization · Decoupled crop-animal system . Soybean $\cdot$ Maize

\section{Introduction}

International trade of food and feed greatly influences global food security and resource sustainability (MacDonald et al. 2015). The trade of agricultural products has increased by more than 10 times during 
the past six decades, and it is likely to continue to grow in the near future (Schmitz et al. 2012). The increasing human population and higher proportion of animal protein in human diets have been major drivers of the increased international trade of food and feed, together with reduced transport and transaction costs for trading, and trade liberalization agreements (Anderson 2010). Agricultural trade has become increasingly important to food supplies and has contributed to global economic growth and poverty reduction (Anderson 2014). However, the rapid development of trade of agricultural products has contributed to deforestation and soil phosphorus (P) mining, as well as to increased emissions of greenhouse gases and reactive nitrogen $(\mathrm{N})$ from agriculture to the environment, and social instability (Bouwman et al. 2017; DeFries et al. 2010; Schipanski and Bennett 2012; Lassaletta et al. 2014a; Suweis et al. 2015).

The trade of food and feed has facilitated the specialization and agglomeration of agricultural production systems, in particular animal production (Naylor et al. 2005; Lassaletta et al. 2014a; Peyraud et al. 2014; Nesme et al. 2015). The spatial disconnection of crop and animal production has been facilitated also by the availability of cheap synthetic fertilizers, which made animal manure virtually redundant for the fertilization of soils and crops, and by technological advances and low feed prices, which made concentrated livestock production and feed imports from distant areas profitably (Billen et al. 2010).

The spatial separation of crop and livestock production and the increased trade of agricultural products have large effects on nutrient cycling, nutrient use efficiency and nutrient losses (Schipanski and Bennett 2012; Lassaletta et al. 2014a; Nesme et al. 2015). The global trade of $\mathrm{N}$ embedded in crop products between large world regions (e.g. North America, Europe, China etc.) has increased from 1.6 to 12.1 Tg N/year during the last 50 years (Lassaletta et al. 2016). Animal feed has the largest proportion in the total amount of $\mathrm{N}$ traded in agricultural products, and soybean and maize have a large share $(\sim 60 \%)$ among traded animal feeds (Lassaletta et al. 2014a). Nearly $25 \%$ of the crop protein used for feed was transported over long distances between continents (Billen et al. 2014). Import of feed has allowed some countries (e.g. Japan, Netherland) to support animal production at high livestock densities. However, the global trade of feed has contributed also to $\mathrm{P}$ surpluses in importing countries, and to soil $\mathrm{P}$ depletion and/or reliance on fertilizer $\mathrm{P}$ import in exporting countries (Schipanski and Bennett 2012; Garrett et al. 2017).

Though global trade of food and feed has greatly increased during the last decades, the number of countries involved in food and feed trade is as yet rather limited, and the characteristics of these countries are not well known. There are a number of possible reasons for countries to import and/or export food and/or feed. For example, import of animal feed will occur when the agricultural land within a country produces insufficient feed for the domestic herd, and/ or when imported feed is cheaper and/or of higher quality than domestically produced feed. Animal production in feed importing countries has to be economically competitive relative to importing animal products from exporting countries, and/or animal production in feed importing countries is supported through governmental policies (for example, to guarantee food safety, quality and security, or to support the agricultural sector).

The main objective of our study was to increase the understanding of the relationships between livestock density, international trade of food and feed, and $\mathrm{N}$ and $\mathrm{P}$ balances at country level, on the basis of statistical data. In the study presented here, we hypothesized that increasing livestock density is a main driver for feed import. Secondly, we hypothesized that increases in livestock density and feed import increase $\mathrm{N}$ and $\mathrm{P}$ surpluses of food systems at country level.

First, we analysed the changes in the number of countries in the world involved in the trade of main crop and animal commodities from 1961 to 2011. Second, we investigated the relationship between changes in livestock density and changes in the import and export of the main feed commodities (i.e. soybean and maize) for selected countries. Third, we examined the relationship between changes in livestock density and $\mathrm{N}$ and $\mathrm{P}$ balances at country level. Fourth, we analyzed the regional variation in livestock density within the selected countries. The results provide new insights into the relationships between livestock density, trade of animal feed commodities, and $\mathrm{N}$ and $\mathrm{P}$ surpluses at country level. 


\section{Materials and methods}

Database analyses

The FAOSTAT (2016) database was used for the analysis of the relative contributions of countries to the total import and export of main food and feed commodities related to animal production. We selected the main cereals (wheat, maize, rice), oil crops (soybean, sunflower, rapeseed, oil palm; including cakes and oil), pulses (a combination of beans, peas and other pulses) and main animal products (milk, bovine meat, pig meat and poultry meat). These commodities cover roughly $62 \%$ (in fresh weight) of the international trade of agricultural products. Comparisons were made for 5-year averages during the periods 1961-2011, to identify the main changes over time in the number of countries involved in trade. The analyses involved 183 countries.

Based largely on Willis (2003) and Shiferaw et al. (2011), we selected soybean and maize as indicators for the trade of feed, as soybean and maize are the main feed items for housed animals. The main soybean and maize importing countries (China, Japan, France, Germany, Indonesia, the Netherlands and Spain) and the main soybean and maize exporting countries (Argentina, Brazil, India and USA) were selected for further analysis of the relationships between changes in livestock density, trade of soybean and maize and $\mathrm{N}$ and $\mathrm{P}$ balances, using the FAOSTAT database. Those countries were selected on the basis of their shares in import and export of soybean and maize during the last 50 years (see SI).

To provide a geographically explicit description of the changes in livestock density, we collected regional data on livestock numbers and agricultural areas from regional and national databases. Due to the limited access to national data sources, we selected five importing countries and two exporting countries here. Regional data for France, Spain, Germany and the Netherlands for the period 2000-2011 were obtained from Eurostat (2016), for China for the period 1996-2011 from NBS (2016), for USA for 2012 from Census of Agriculture by USDA (2016), and for Brazil for 2006 from Census of Agriculture by IBGE (2016). Those databases provide animal numbers (dairy cattle, other cattle, pigs, poultry, sheep and goats) and agriculture areas for each region/state/province within a country.
Livestock density was expressed as livestock units (LU) per ha of agricultural area, in which the relative weight of a mature dairy cow is set at 1 and the other livestock categories at 0.5 for beef cattle, 0.35 for pigs, 0.012 for laying hens, 0.018 for other poultry, and 0.1 for sheep and goats (Eurostat 2009; Lesschen et al. 2011). The feed demand for 1 LU roughly ranges between 4000 and $7000 \mathrm{~kg}$ dry matter per year, depending on milk yield, quality of the feed, and production system.

\section{Calculations of nutrient balances}

Balances of $\mathrm{N}$ and $\mathrm{P}$ were estimated for the whole food supply system (i.e. production, processing and retail) at country level, as follows:

$$
\begin{aligned}
\mathrm{N}(\mathrm{P}) \text { balance }= & \text { Input }_{\text {Fertilizer }}+\text { Input }_{\mathrm{BNF}} \\
& + \text { Input }_{\text {Lightning }} \\
& + \text { Input }_{\text {Import crop and animal }} \\
& - \text { Output }_{\text {Food supply }} \\
& - \text { Output }_{\text {Export crop and animal }}
\end{aligned}
$$

Inputs included $\mathrm{N}$ and $\mathrm{P}$ via synthetic fertilizers (Input $_{\text {Fertilizer }}$ ), biological $\mathrm{N}_{2}$ fixation (Input ${ }_{\mathrm{BNF}}$ ), lightning $\mathrm{N}$ fixation (Input ${ }_{\text {Lightning }}$ ), import of plant and animal products from other countries (Input Im- $_{\text {- }}$ port crop and animal). Outputs included $\mathrm{N}$ and $\mathrm{P}$ in the food

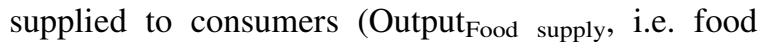
consumed and food wasted by consumers) and $\mathrm{N}$ and $\mathrm{P}$ in exported plant and animal products to other

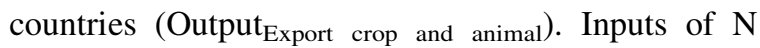
and $\mathrm{P}$ in manure and compost, and of reduced $\mathrm{N}$ in atmospheric deposition were not accounted for as these are largely recycled nutrients within a country. A detailed description of nutrient balance calculation is presented in the supplementary information accompanying this paper.

At regional level, we estimated $\mathrm{N}$ and $\mathrm{P}$ balances of cropping systems (and not at food systems level, due to lack of data related to the exchange of food and feed commodities between regions), using Eq. 2.

$\mathrm{N}(\mathrm{P})$ balance in crop production system

$$
\begin{aligned}
= & \text { Input }_{\text {Fertilizer }}+\text { Input }_{\text {Manure }}+\text { Input }_{\text {BNF }} \\
& + \text { Input }_{\text {Deposition }}+\text { Input }_{\text {Seed }}+\text { Input }_{\text {Irrigation }} \\
& + \text { Input }_{\text {Wastes }}+\text { Input }_{\text {By-products }} \\
& - \text { Output }_{\text {Crop production }}
\end{aligned}
$$


where Input $_{\text {Manure }}=$ input via animal manure, Input $_{\text {Wastes }}=$ input via human wastes (kitchen wastes, excrements), Input $_{\text {By-products }}=$ input via residues from food processing sectors.

Estimations for China were made with the NUFER model, and for European countries with the MITERRA-Europe model. NUFER model is a static mass flow model for the whole food productionconsumption chain in China and operates at the regional level (Ma et al. 2010). MITERRA-Europe model is an environmental assessment model for nutrient losses and greenhouse gases emission in EU27 at regional and country level (Lesschen et al. 2011). Information on calculations and data sources is detailed in the supplementary information accompanying this paper.

\section{Statistical analyses}

A descriptive statistical analysis was carried out using R software ( $R$ Core Team 2013). We used linear regression models to analyse the relationships between livestock density, soybean and maize net import (import-export) and N, P balances in the main soybean and maize importing countries.

\section{Results}

Changes in the trade of food and feed commodities

The trade of main food and feed commodities has increased by a factor of 5-20 during the period 1961-2011 (Fig. 1). Wheat has remained the main trade commodity in terms of mass. Rice was the least traded cereal while maize had the largest increase in trade among cereals. Changes in the trade of oil crops and animal products were much larger than that of cereals. Soybean showed the largest increase; the trade of soybean $(156 \mathrm{Tg})$ has become almost as large as that of wheat (167 Tg) in 2007-2011. Poultry meat showed the largest increase among animal products; the trade of poultry meat has surpassed that of beef products.

The number of main food and feed exporting countries is smaller than the number of main importing countries (Table 1). Changes in the number of countries involved in the import of food and feed products has been also larger than the changes in the number of countries involved in export during the period
1961-2011. This suggests a greater specialization of food and feed production by some countries and a greater reliance on import of food and feed by other countries. Specialization is especially evident among oil palm, soybean and maize producing countries.

Approximately $72 \%$ of the soybean and $57 \%$ of the maize produced in the world were used to feed animals in 2007-2011 (Table S3). The percentage of maize used for animal feeding has decreased from $71 \%$ in 1961-1965 to $57 \%$ in 2007-2011 because of the increased use of maize for biofuel, notably in USA and Brazil. The increased feed demand has greatly contributed to the increased trade of soybean and maize. The total trade of soybean increased from $8 \mathrm{Tg}$ in the early 1960 s to a mean of $156 \mathrm{Tg}$ in 2007-2011. The trade of maize has increased from 20 to $110 \mathrm{Tg}$ during this period. The export of soybean and maize remained concentrated in few countries, only 2-5 countries accounted for $90 \%$ of the total soybean export, and 8-10 countries accounted for $90 \%$ of the total maize export during the period 1961-2011 (Table 1). In contrast, the number of soybean and maize importing countries have increased significantly. A total of 14 countries accounted for $90 \%$ of the total soybean import in 1961-1965, and 36 countries accounted for $90 \%$ of the total soybean import in 2007-2011. Similarly, 17 countries accounted for $90 \%$ of the total import of maize in 1961-1965, while 41 countries accounted for $90 \%$ of the total maize import in 2007-2011.

In 2007-2011, USA, Argentina, Brazil together accounted for $81 \%$ of the total soybean export and for $69 \%$ of the total maize export (Fig. S1). Interestingly, India was a net importer of soybean and maize in the 1960s, but has become the fifth biggest exporter of soybean $(3.7 \mathrm{Tg})$ and sixth biggest exporter of maize (3.1 Tg) in 2007-2011. The biggest importers of soybean and maize in 2007-2011 were China, The Netherlands, Japan, Germany, Spain and Indonesia. China accounted for $31 \%$ of the total soybean import in 2007-2011. It surpassed Japan as the main importer of soybean and maize in Asia in 2000. Indonesia did not import any soybean in 1960s, but has become the third biggest importer in 2007-2011, mainly to support the booming poultry production sector. The Netherlands, Germany and Spain were the main importers of both soybean and maize, while France was the sixth biggest importer of soybean and the fourth biggest exporter of maize in the world. 

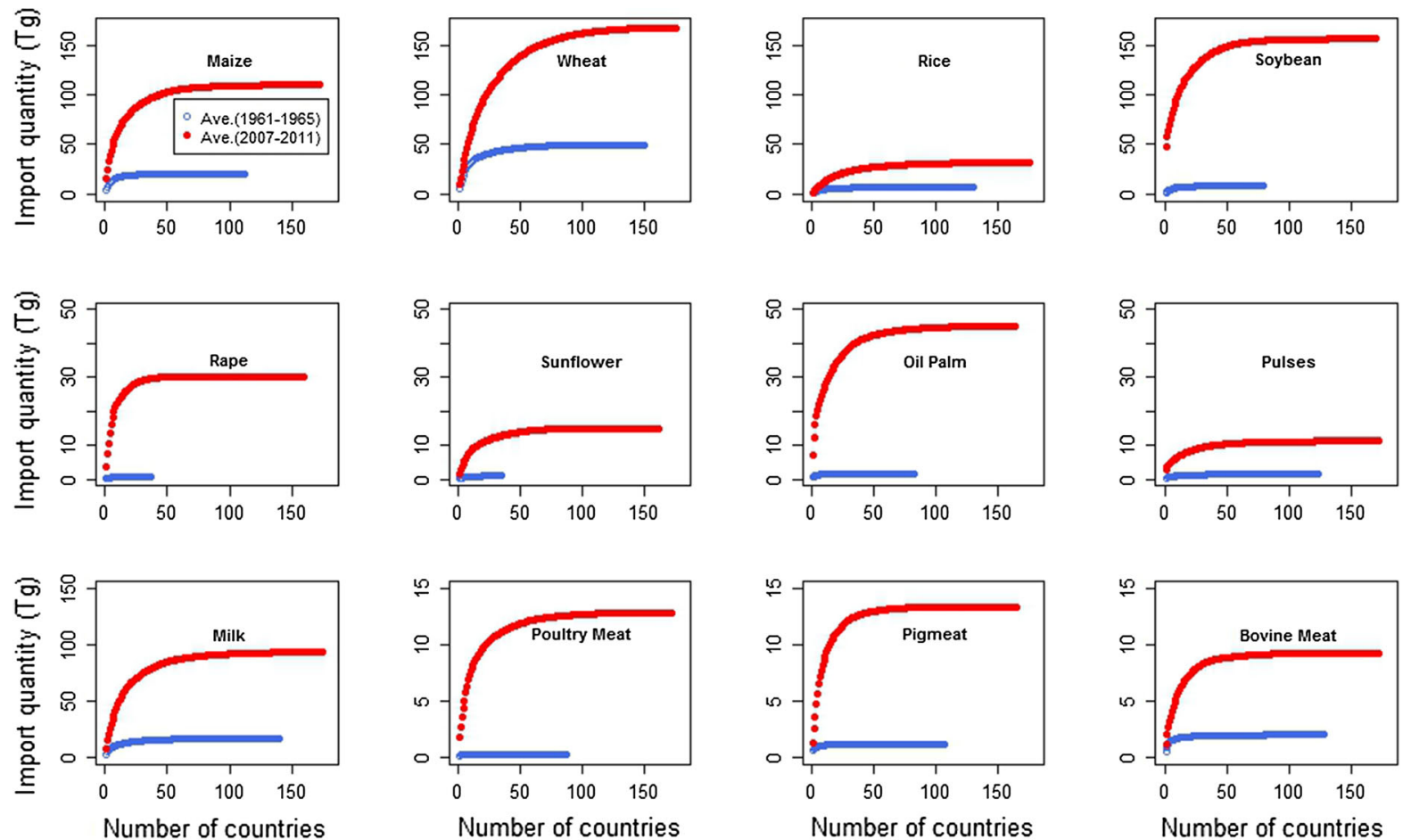

Fig. 1 Cumulative mean total import of main crop and animal products by the countries in the world in 1961-1965 (blue) and in 2007-2011 (red). Countries are plotted in descending order of
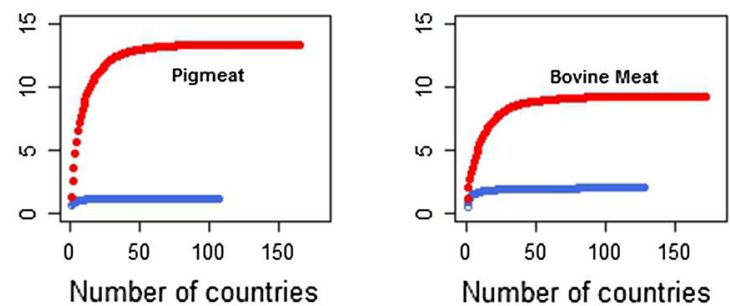

importance, with each dot representing a 5-year average value. Note the difference in scale of the Y-axis. Source: FAOSTAT (2016) and authors' calculations. (Color figure online)

Changes in livestock density of main feed importing and exporting countries

Median livestock density in the world has increased from $0.72 \mathrm{LU} / \mathrm{ha}$ in $1961-1965$ to $0.95 \mathrm{LU}$ in 2007-2011 (Liu et al. 2017). The increase in livestock density in the main soybean and maize importing countries was faster compared to most other countries. For example, livestock density in The Netherlands increased from a mean of 2.0 LU/ha in 1961-1965 to 4.9 LU/ha in 2007-2011 (Fig. S2). During the same period, livestock density in Japan increased from 0.8 to $2.2 \mathrm{LU} / \mathrm{ha}$, in China from 0.5 to $1.5 \mathrm{LU} / \mathrm{ha}$, and in Spain from 0.2 to $0.7 \mathrm{LU} / \mathrm{ha}$. Total livestock density did not change much in Germany, France and Indonesia (Fig. S2), but the number of poultry and/or pigs increased relative to the number of ruminant animals (Fig. 2).

Changes in livestock density were correlated with changes in the net import of soybean and maize (expressed in mass per unit utilized agricultural area; UAA), though with large variations between countries

(Fig. 3a, b, Table S4). The import of soybean varied between countries from 121 to $1814 \mathrm{~kg} / \mathrm{LU}$ and the import of maize from 15 to $600 \mathrm{~kg} / \mathrm{LU}$ in 2011 . The data suggests that the import of soybean and maize accounted for $3 \%$ to more than $60 \%$ of the total feed demand in those selected countries (based on the assumption that feed intake is $4 \mathrm{Mg} / \mathrm{LU} /$ year).

Changes in livestock density were relatively small and not correlated with the export of soybean and maize in the main soybean and maize exporting countries, e.g. Argentina, Brazil and USA (Fig. 3c, d). These countries have relatively large areas of utilized agricultural land per capita (Table S5). The relative increase in production of soybean and maize in these countries was larger than the relative increase of livestock production (Table S6). India is a special case; it has a high population density and little utilized agricultural area per capita $(0.15 \mathrm{ha}$ /capita), a relatively high livestock density (1.3 LU/ha), an increasing cattle and poultry stock (Fig. 2), and yet managed to increase the export of soybean and maize. 
Table 1 International trade of food and feed commodities, as percentage of total production, and the number of main importing and exporting countries, i.e., accounting jointly 90\% to the total import and export, for the periods 1961-1965 and 2017-2011. Source: FAOSTAT (2016) and authors' calculations

\begin{tabular}{|c|c|c|c|c|c|c|}
\hline \multirow{3}{*}{$\begin{array}{l}\text { Food/feed } \\
\text { commodities }\end{array}$} & \multicolumn{3}{|l|}{ Period 1961-1965 } & \multicolumn{3}{|l|}{ Period 2007-2011 } \\
\hline & \multirow[t]{2}{*}{$\begin{array}{l}\text { International trade, } \\
\text { in } \% \text { of production }\end{array}$} & \multicolumn{2}{|c|}{$\begin{array}{l}\text { Number of countries } \\
\text { accounting } 90 \% \text { to }\end{array}$} & \multirow[t]{2}{*}{$\begin{array}{l}\text { International trade, } \\
\text { in } \% \text { of production }\end{array}$} & \multicolumn{2}{|c|}{$\begin{array}{l}\text { Number of countries } \\
\text { accounting } 90 \% \text { to }\end{array}$} \\
\hline & & Import & Export & & Import & Export \\
\hline Maize & 10 & 17 & 8 & 13 & 41 & 10 \\
\hline Wheat & 20 & 39 & 5 & 25 & 66 & 21 \\
\hline Rice & 4 & 32 & 9 & 7 & 61 & 11 \\
\hline Soybean & 28 & 14 & 2 & 65 & 36 & 5 \\
\hline Rape & 17 & 11 & 9 & 51 & 20 & 15 \\
\hline Sunflower & 12 & 13 & 5 & 44 & 43 & 16 \\
\hline Oil palm & 74 & 13 & 14 & 81 & 37 & 3 \\
\hline Pulses & 3 & 35 & 29 & 17 & 42 & 15 \\
\hline Milk & 5 & 36 & 11 & 13 & 47 & 24 \\
\hline Poultry meat & 3 & 10 & 5 & 14 & 42 & 12 \\
\hline Pig meat & 4 & 10 & 10 & 13 & 27 & 13 \\
\hline Bovine meat & 6 & 15 & 17 & 14 & 31 & 18 \\
\hline
\end{tabular}

Changes in nutrient balances of main feed importing and exporting countries

The relationships between changes in livestock density and $\mathrm{N}$ and $\mathrm{P}$ balances of the food systems of main soybean and maize importing countries were positive during 1961-2011 (Fig. 4, Table S7). In those importing countries, the $\mathrm{N}$ balance increased $75-306 \mathrm{~kg} / \mathrm{ha}$ and the $\mathrm{P}$ balance $2-49 \mathrm{~kg} / \mathrm{ha}$, when livestock density increased 1 LU/ha (Table S7). The differences between countries were larger for $\mathrm{P}$ than for $\mathrm{N}$. Changes in $\mathrm{N}$ and $\mathrm{P}$ balances over time were smaller, and absolute balances much lower, in the main soybean and maize exporting countries than in the main importing countries. Some exporting (e.g. Argentina) and some importing countries (e.g. Indonesia) tended to have negative $\mathrm{P}$ balances.

The $\mathrm{N}$ and $\mathrm{P}$ balances of the main importing countries were positively related to the import of maize and soybean, but with large differences between countries (Figs. 5a, b, 6a, b). The import of soybean accounted for $12-36 \%$ of the $\mathrm{N}$ balance in importing countries, and the import of maize for $0-26 \%$. The contribution of soybean and maize imports to the $\mathrm{N}$ balance was relatively large in Japan, larger than that of The Netherlands, with a much higher livestock density.

Changes in the export of soybean and maize were not reflected in changes in $\mathrm{N}$ and $\mathrm{P}$ balances of the main soybean and maize exporting countries (Figs. 5c, $\mathrm{d}, 6 \mathrm{c}, \mathrm{d})$. Though massive amounts of soybean and maize were exported by these countries (Table S5), the export of $\mathrm{N}$ and $\mathrm{P}$ was still relatively small when expressed per unit of utilized agricultural area (Figs. 5, 6). Hence, the impacts of soybean and maize trade on overall $\mathrm{N}$ and $\mathrm{P}$ balances at country level were much larger for the importing countries than exporting countries.

Variations in livestock density and nutrient balance within countries

Livestock density distributions within countries were highly skewed, i.e., the mean was higher than the median livestock density and some regions/provinces/ states had a very high livestock density (Fig. 7). There is a tendency that the spatial differences within countries increased with an increase in mean livestock 

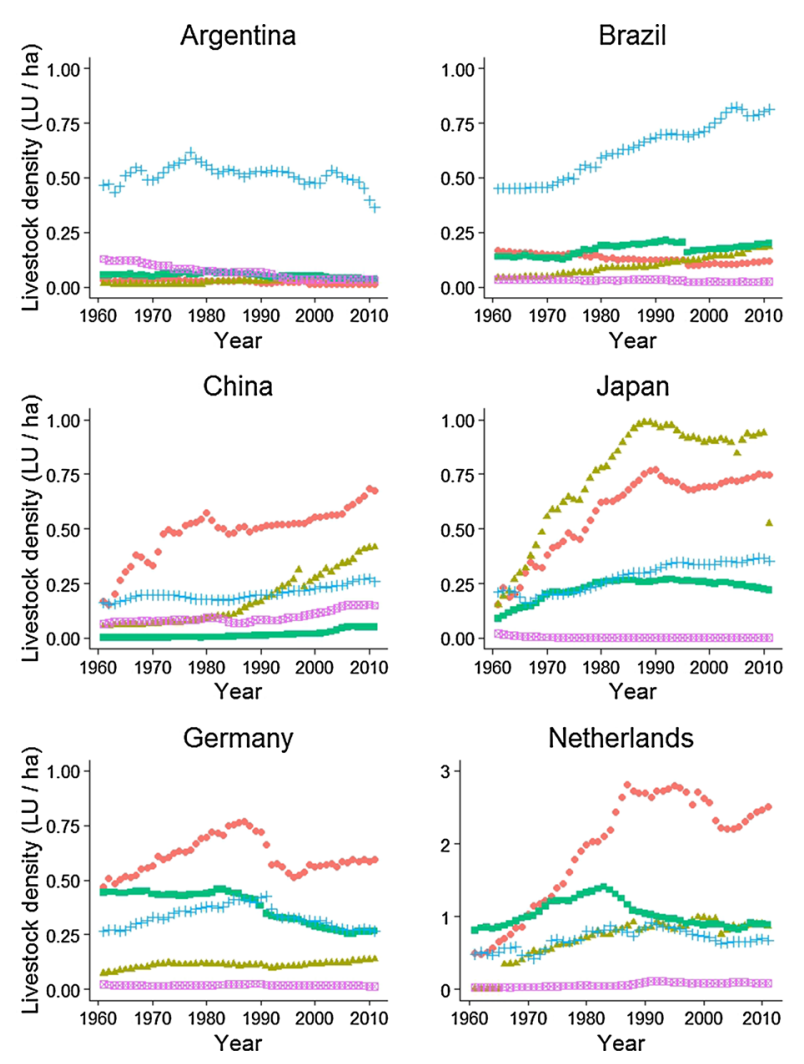

Fig. 2 Changes in livestock density (LU/ha) of main animal categories in soybean and maize exporting countries (upper four panels) and importing countries (lower 7 panels) during the

density. However, this tendency may be confounded with differences in the size of regions/provinces/states between countries. For example, The Netherlands is smaller than almost any region/province/state in USA, Brazil, France, Spain, Germany and China. In USA, livestock density ranged from $0.02 \mathrm{LU} / \mathrm{ha}$ in the largest state Alaska to $2.6 \mathrm{LU} / \mathrm{ha}$ in one of the smallest states Delaware, in China from $0.1 \mathrm{LU} / \mathrm{ha}$ in Tibet to 3.9 LU/ha in Shandong, and in The Netherlands from $0.5 \mathrm{LU} / \mathrm{ha}$ in the province Zeeland to nearly $10 \mathrm{LU} / \mathrm{ha}$ in nearby Noord-Brabant. Within the 30 communities in Noord Brabant, livestock density ranged from 0.5 to 12 LU/ha.

Changes in spatial variations of livestock density within countries have been rather small in European countries during the last 10 years (Fig. S3). In some countries, there has been an ongoing concentration; for example, livestock density in animal-rich Catalonia in Spain increased from 2.3 LU/ha in 2000 to $2.9 \mathrm{LU} / \mathrm{ha}$ in 2011, while the density in few other rich regions
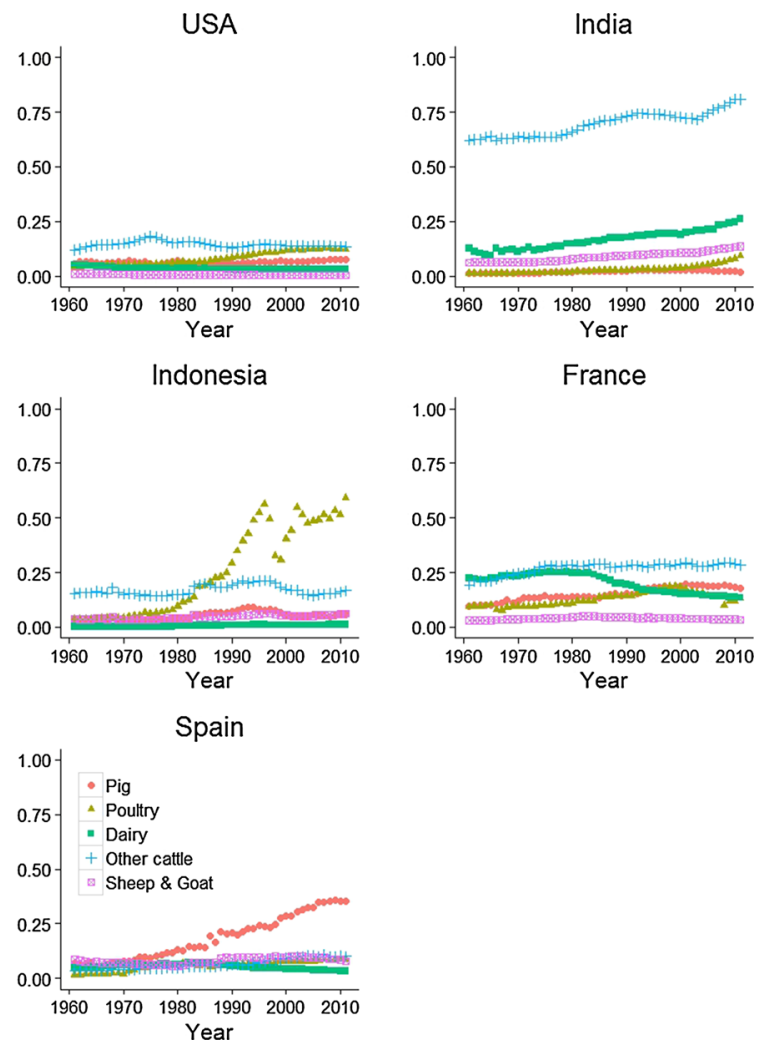

period 1961-2011. Note the difference in Y-axis for the Netherlands. Source: FAOSTAT (2016) and authors' calculations

decreased. Two contrasting trends have been evident in China (Fig. S4). There were increases in livestock density in most regions, but decreases in urbanized regions with very high livestock density (e.g. Beijing, Shanghai, Guangdong and Shandong). In low-populated provinces (e.g. Heilongjiang, Tibet, Inner Mongolia, and Qinghai) livestock density was relatively low and stable $(<0.55 \mathrm{LU} / \mathrm{ha})$.

Variations in livestock density between regions were related to regional variations in the $\mathrm{N}$ balances of cropping system (Fig. 8). The $\mathrm{N}$ balance of cropping system at regional level tended to increase on average by $90 \mathrm{~kg} / \mathrm{ha}$ in China and by $33 \mathrm{~kg} / \mathrm{ha}$ in France when mean livestock density increased 1 LU/ha. Such relationships were more diffuse or absent in the Netherlands, mainly because of environmental regulations. On average, more than half of the amount of animal manure produced on livestock farms in the Netherlands, has to be transferred to other farms with room for manure application within $\mathrm{N}$ and $\mathrm{P}$ 

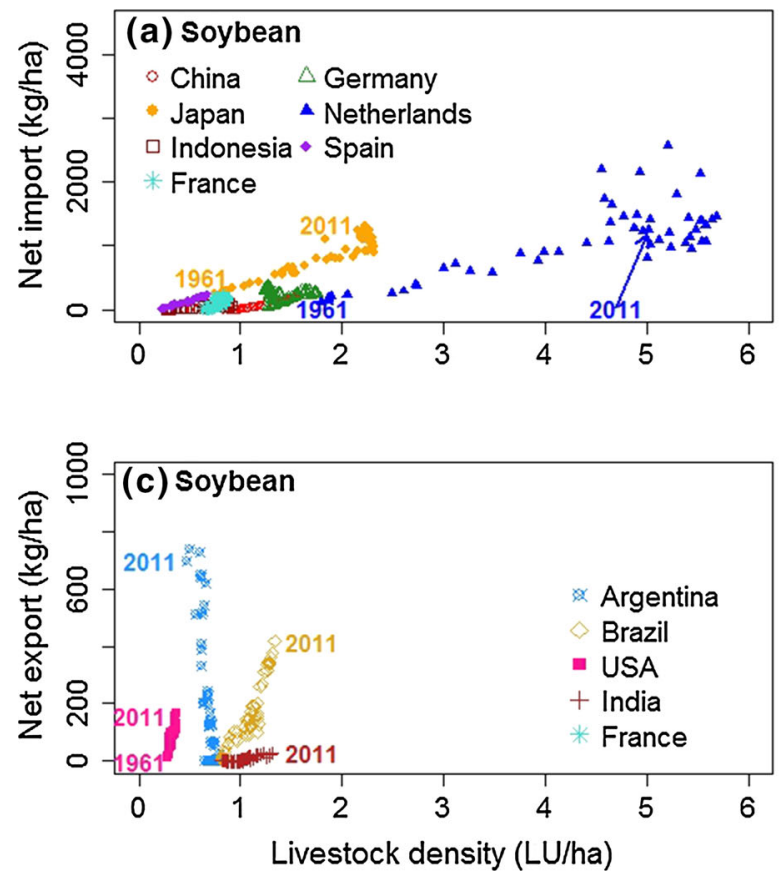

Fig. 3 Changes in the relationships between livestock density and net import of soybean (a) and maize (b), and net export of soybean (c) and maize (d) for selected countries during 1961-2011. Livestock density (in livestock units) and import and export (in mass) are expressed per unit of utilized agricultural area (LU/ha). Net import is defined as the difference

application limits, and approximately $25 \%$ of the manure produced has to be exported to other countries (CDM 2016).

\section{Discussion}

Intercontinental trade of soybean and maize

During the past five decades, intercontinental trade of soybean and maize has increased exponentially. Around $70-80 \%$ of the traded soybean and maize originated from USA, Brazil, Argentina and India. The number of main exporting countries did not change much during the period 1961-2011, but the number of importing countries increased strongly (Table 1). The selected main importing countries accounted for $56 \%$ of the imported soybean and for $38 \%$ of the imported maize in 1961-1965, and they accounted for 54\% of traded soybean and $31 \%$ of the traded maize in 2007-2011.
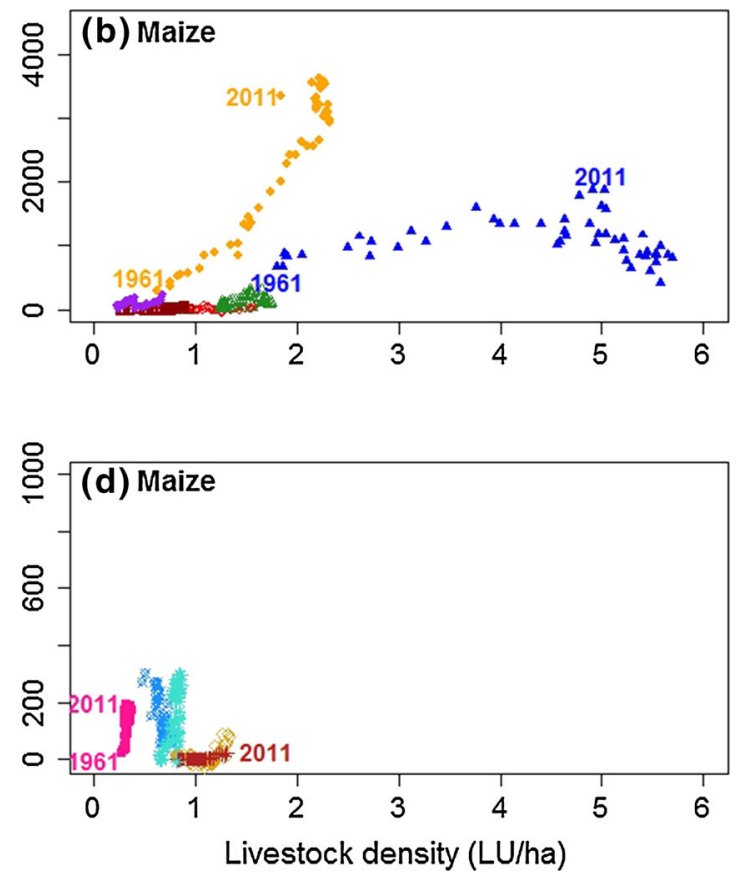

between import and export (import-export), net export is the reverse. Results for the 1960s are at the bottom/left of the figure; results for the 2000s tend to be in the upper/right of the figure. Note the differences in Y-axis. Source: FAOSTAT (2016) and authors' calculations

The increased import of soybean and maize in main importing countries is strongly related to increases in animal production and livestock density (Fig. 3), which is largely demand-driven (Steinfeld et al. 2006). The share of animal protein in human diets has significantly increased in many developed and developing countries during the last 5 decades (Kastner et al. 2012). In response, median livestock density in the world increased from $0.72 \mathrm{LU} /$ ha in 1960 to 0.95 LU/ha in 2010 (Liu et al. 2017). In Spain, the share of animal protein in human diets increased from 33 to $64 \%$, livestock density from 0.2 to $0.6 \mathrm{LU} / \mathrm{ha}$ and soybean import from 0 to $300 \mathrm{~kg} / \mathrm{ha}$ during the last 5 decades (Lassaletta et al. 2014c). However, increases in animal production are not always related to increased domestic consumption of animal-sourced food but also to increased specialization and export orientation. For example, more than half of the animal production in The Netherlands is exported. In addition, a significant amount of crop and animal products are imported, processed and then exported again. 

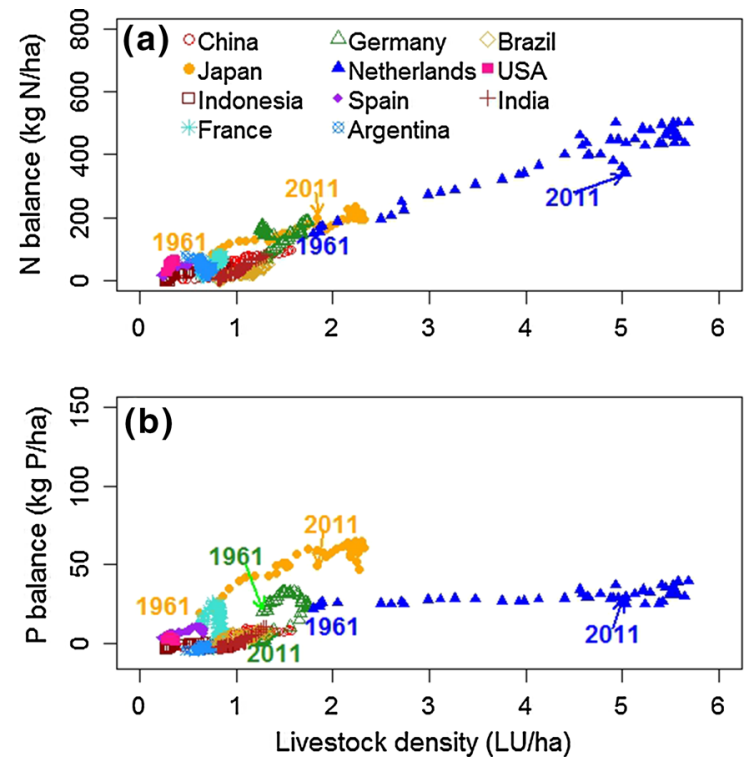

Fig. 4 Changes in the relationship between livestock density and nitrogen $(\mathrm{N})$ balances (a, upper panel) and phosphorus (P) balances (b, lower panel) for selected countries during 1961-2011. Source: FAOSTAT (2016) and authors' calculations
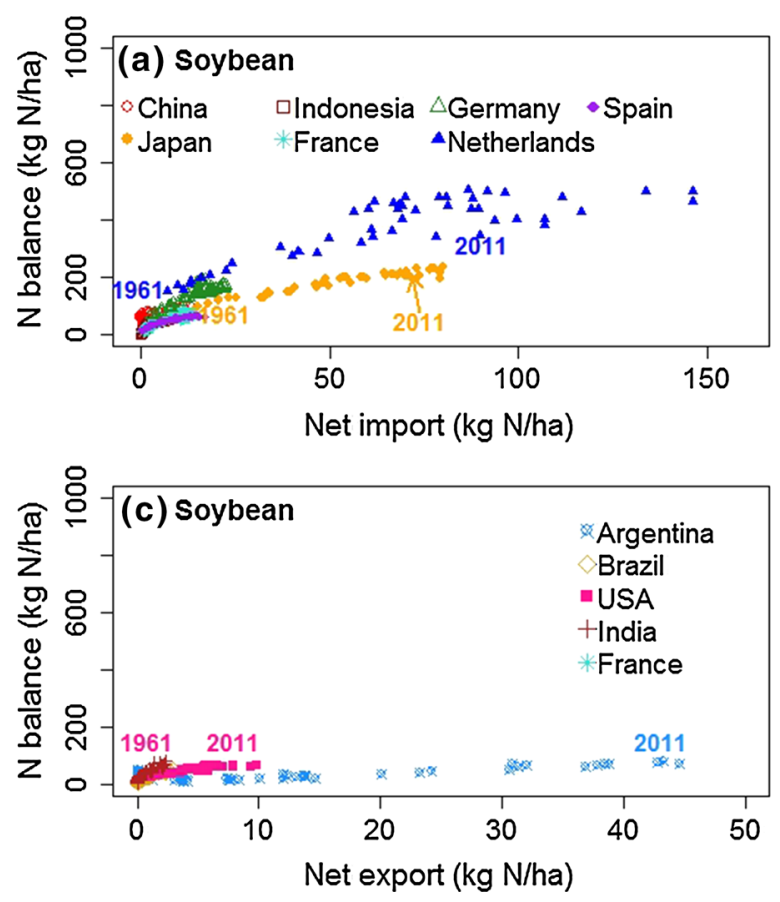

Fig. 5 Changes in the relationship between the net import of soybean (a) and maize (b) and nitrogen ( $\mathrm{N}$ ) balances (upper panels), and between the net export of soybean (c) and maize
Another driver for increased soybean and maize import is the increase in monogastric animals relative to ruminant animals (Fig. 2; Liu et al. 2017). Pigs and poultry are increasingly held on landless livestock farms where essentially all feed is imported from elsewhere. The mean share of soybean meal in compound feed in EU-27 was 24\% in 2007, with larger percentages for the feed of pigs $(29 \%)$ and broilers (37\%) than cattle (10-14\%) (Van Gelder et al. 2008; Bues et al. 2013). Modern pig and poultry farms in China and Japan are also increasingly dependent on the import of soybean and maize from the Americas, in part because of the collapse of the traditional backyard systems (Bai et al. 2014).

Political agreements have also contributed to increased trade of food and feed. The large soybean import in EU-27 is related in part to the (former) Common Agricultural Policy (CAP) supporting cereal and animal production, the Blair House Agreement (1992) for duty free soybean import, and the Berlin Agreement (1999) for decreasing aids to oilseeds and to open the European market to global trade (Bertheau
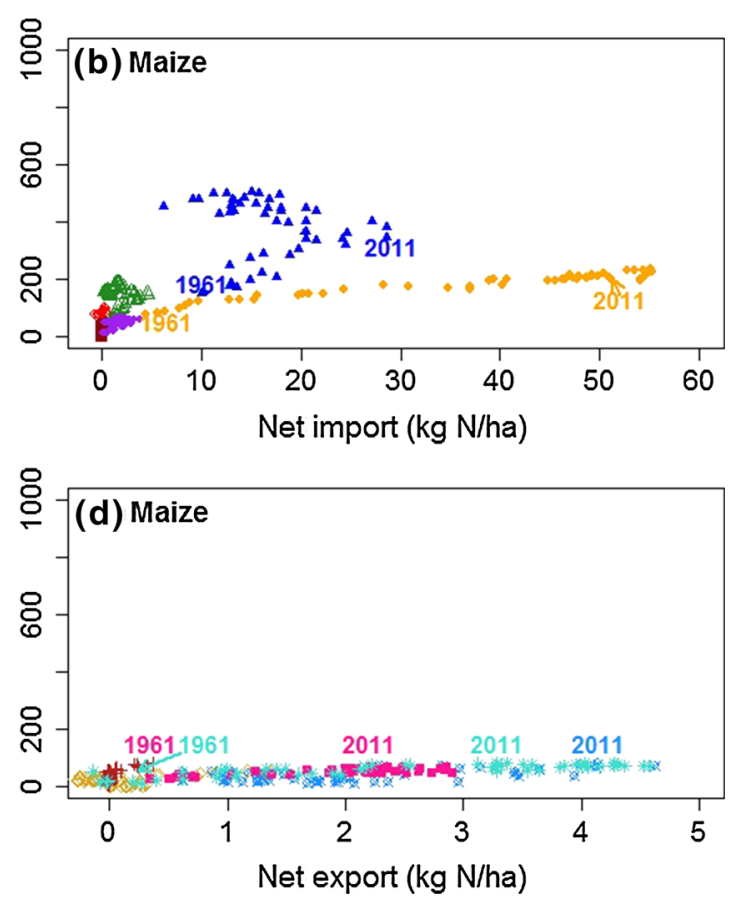

(d) and nitrogen (N) balances (lower panels) for selected countries during 1961-2011. Source: FAOSTAT (2016) and authors' calculations 

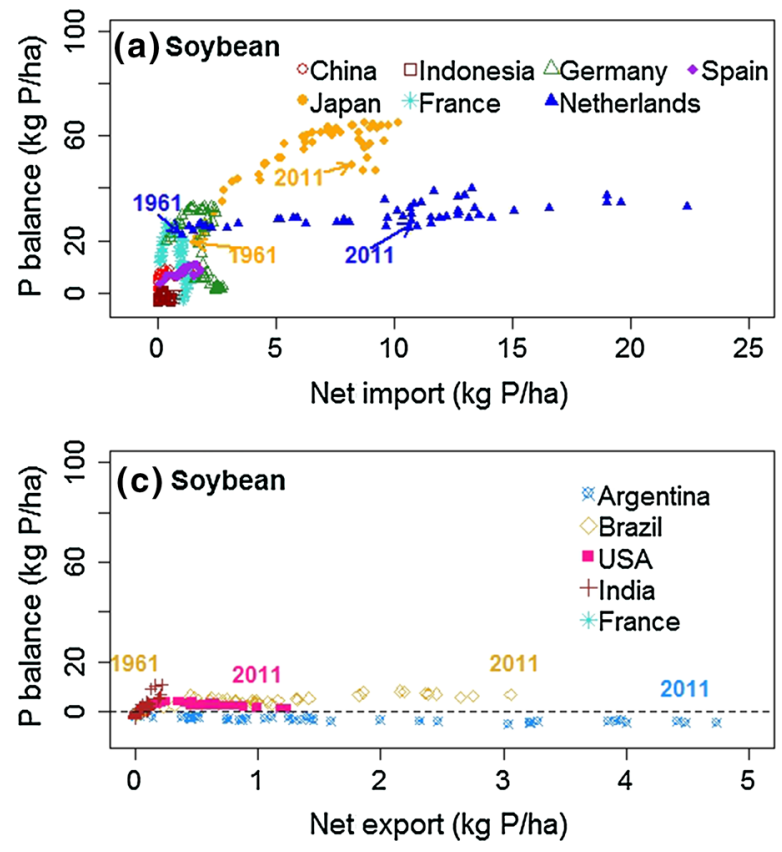

Fig. 6 Changes in the relationship between the net import of soybean (a) and maize (b) and phosphorus (P) balances (upper panels), and between the net export of soybean (c) and maize
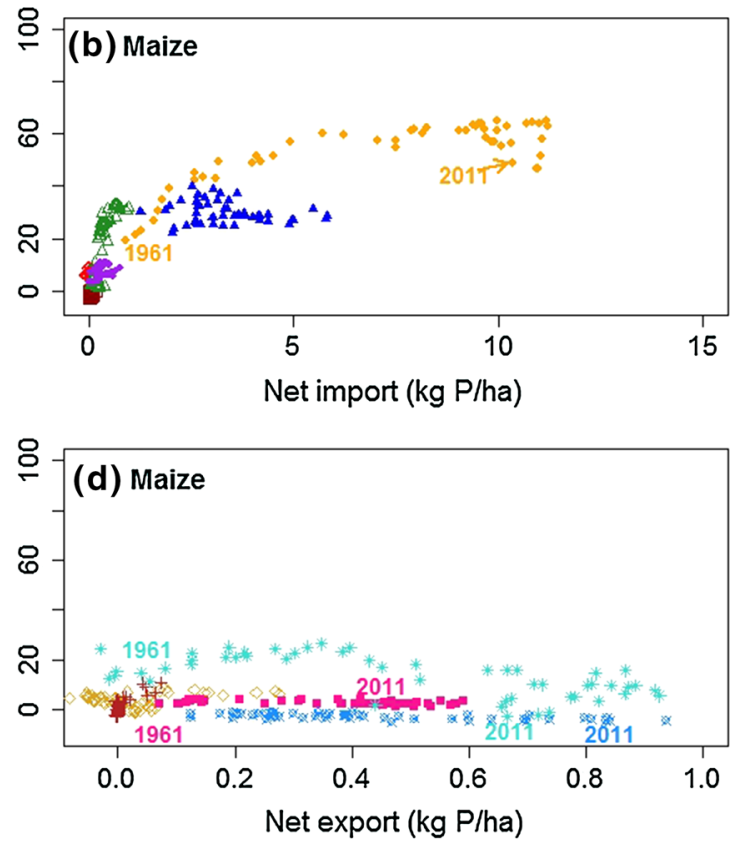

(d) and phosphorus (P) balances (lower panels) for selected countries during 1961-2011. Source: FAOSTAT (2016) and own calculations

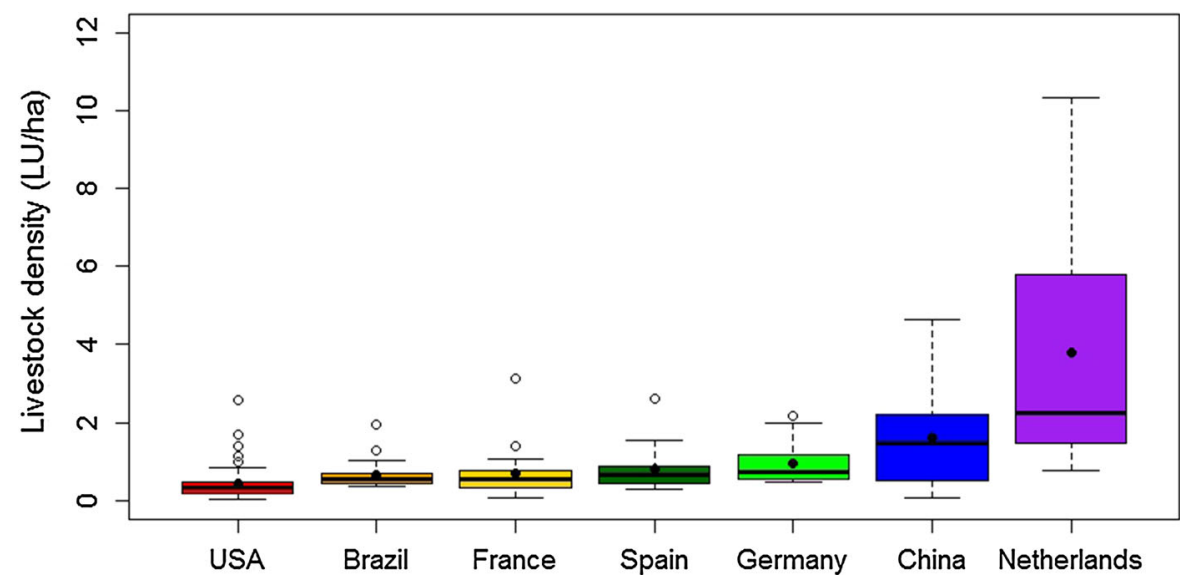

Fig. 7 Box plots of livestock density per region within selected countries. Data for USA relate to 52 states in 2012, for Brazil to 27 states in 2006, for France to 22 regions in 2007, for Spain to 16 regions in 2007, for Germany to 14 Bundesländer in 2007, for China to 31 provinces in 2010, and for Netherlands to 12

and Davison 2011). Further, breeding and improved agronomic practices have greatly contributed to yield increases, and as a result have made EU-27 largely self-sufficient as regards to maize and to a lesser extent wheat (USDA 2015). The strong increase in maize productivity also explains why France has become a provinces in 2007. Lines in boxes indicate medians, black dots indicate means, lower and upper levels of boxes the 25 and 75 percentiles, and the lower and upper bars the 5 and 95 percentiles. Open circles show extreme values. Source: National databases and authors' calculations

maize exporter, while pig and poultry production have increased simultaneously. Breeding and improved practices have also increased soybean yields in the main soybean exporting countries (USA, Argentina and Brazil), although increased acreages of soybean have also contributed to the increase in total 

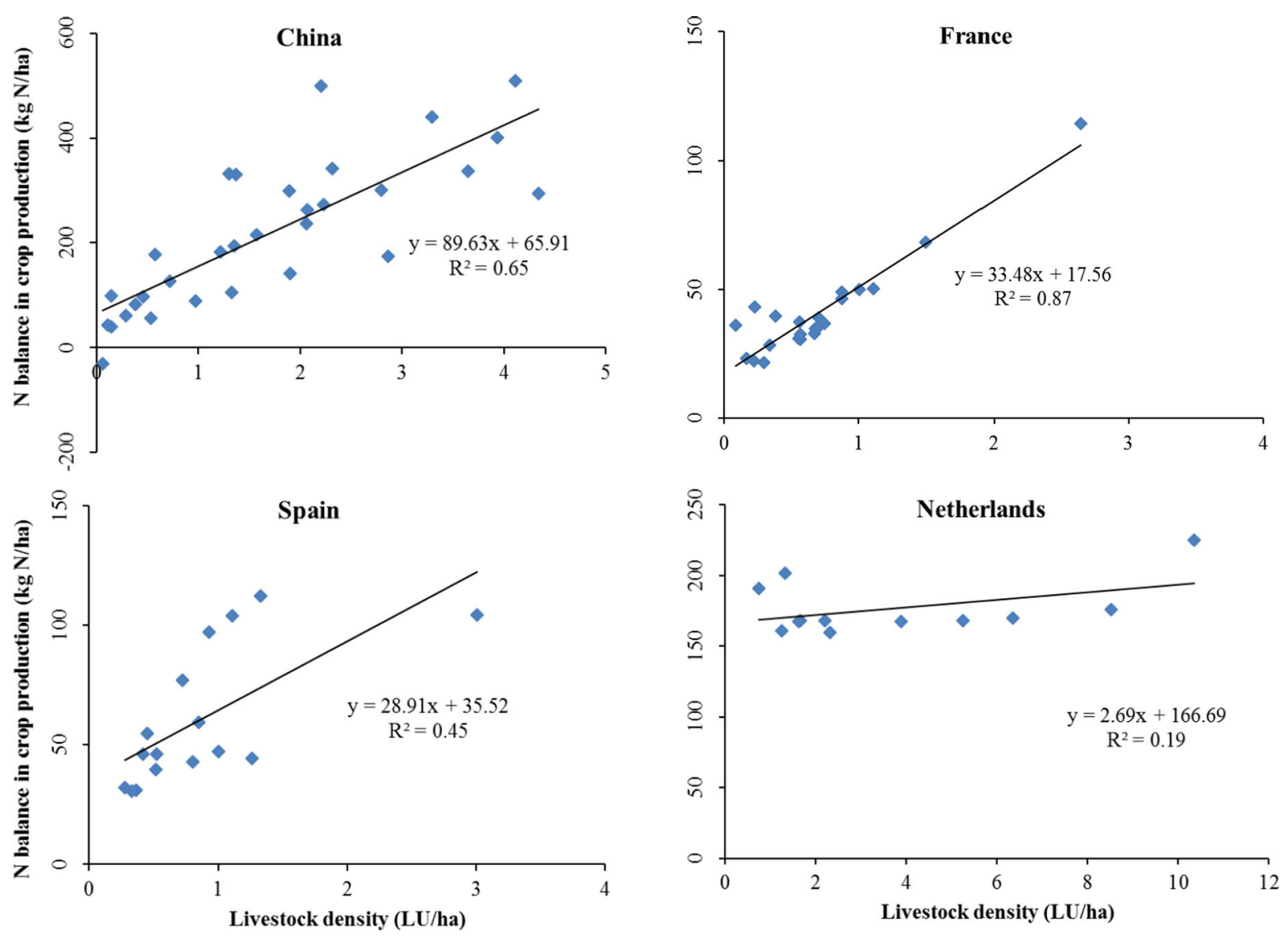

Fig. 8 Relationship between livestock density and nitrogen (N) balance of cropping system at regional level in China, France, Spain and Netherlands. Data for China relate to 31

production. The increases in production of soybean and maize have been larger than the growth rate of livestock production in these countries (Table S6).

India is a special case here. Despite its large human population and cattle herd, it has recently become an exporter of soybean and maize. Livestock rearing is an integral part of the agricultural system in India, with bovines and small ruminants as most dominant animal categories. These animals are largely fed through grazing and scavenging of grass, crop residues and byproducts (Swamy and Bhattacharya 2006; Kumar and Singh 2008). However, the developing poultry industry is largely fed on soybean and maize, and the export of soybean and maize may be just an intermediate event (Hellin et al. 2015; Hules and Singh 2017).

provinces in 2005, for France to 22 regions in 2010, for Spain to 16 regions in 2010, and for Netherlands to 12 provinces in 2007. Source: National databases and authors' calculations

Agglomeration of livestock production and nutrient balances

Balances of $\mathrm{N}$ and $\mathrm{P}$ are indicators for the pressure of food systems on the environment. Balances in this study were based on the inputs and outputs of $\mathrm{N}$ and $\mathrm{P}$ in the food production-processing/retail system of a country. The system encompasses the crop production sector, the animal production sector and the food processing and retail sectors. These system boundaries were chosen because the trade of food and feed affects all these sectors directly or indirectly, as well as affects the composition of the food consumed domestically. Output was defined as the net food output for domestic use and the net export of food and feed, as follows from the FAO databases. The calculation procedure of output follows the one outlined by $\mathrm{Ma}$ et al. (2010, 2012). However, output from the crop and 
animal production sectors used for industrial purposes, including bioenergy production, was neglected due to lack of data. The $\mathrm{N}$ in non-food output at country level is likely to be $<10 \%$ and the $\mathrm{P}$ in non-food output is likely to be $<20 \%$ (Ma et al. 2010; Van Dijk et al. 2016). Hence, our $\mathrm{N}$ and $\mathrm{P}$ balances are likely overestimates, because of the neglect of non-food output. Our N and P balances of the food productionprocessing sector are also higher than those of agricultural systems, because losses in the food processing and retail sectors are included.

The positive relationship between livestock density and $\mathrm{N}$ and $\mathrm{P}$ balances at national level (Fig. 4, Table S7) and regional level (Fig. 8) suggests that $\mathrm{N}$ and $\mathrm{P}$ in manure and in residues of the processing industry and retail sectors were not effectively recycled in the food system. Balances of $\mathrm{N}$ and $\mathrm{P}$ were also positively related to the import of soybean and maize in the main importing countries but not in the exporting countries (Figs. 5, 6). In the main importing countries, the $\mathrm{N}$ balance increased $75-306 \mathrm{~kg} / \mathrm{ha}$ and the $\mathrm{P}$ balance $2-49 \mathrm{~kg} / \mathrm{ha}$, when livestock density increased 1 LU/ha (Fig. 4, Table S7). The mean change in $\mathrm{N}$ balance per LU is rather similar to the excretion coefficient of dairy cattle (Gerber et al. 2005; Velthof et al. 2015), which indicates indeed that the differences in $\mathrm{N}$ balance are related to the $\mathrm{N}$ excreted by livestock. The changes in $\mathrm{P}$ balance per $\mathrm{LU}$ is more variable between countries than the changes in $\mathrm{N}$ balances, mainly because of the differences in $\mathrm{P}$ fertilizer use. For example, fertilizer $\mathrm{P}$ input in Japan increased from $26 \mathrm{~kg} P / \mathrm{ha}$ in 1961 to $63 \mathrm{~kg}$ $\mathrm{P} / \mathrm{ha}$ in 2011, while in the Netherlands it decreased from $23 \mathrm{~kg} \mathrm{P} / \mathrm{ha}$ in 1961 to $8 \mathrm{~kg} \mathrm{P} /$ ha in 2011. The latter is related to increased awareness of the fertilization value of animal manure and soil phosphorus, and to environmental regulations, which have increased the fertilizer $\mathrm{N}$ and $\mathrm{P}$ values of animal manures and have decreased the fertilizer $\mathrm{N}$ and $\mathrm{P}$ inputs into agriculture (Velthof et al. 2014; Van Grinsven et al. 2016).

International trade of food and feed has contributed to the further specialization and agglomeration of agricultural systems in importing as well as exporting regions, and hence to the spatial uncoupling of livestock production and crop production (Naylor et al. 2005; Thornton 2010; Schipanski and Bennett 2012). Our study does not allow to identify causal relationships and the main driving forces; likely international trade, specialization, agglomeration, and intensification have interacted upon each other, depending also on the region-specific conditions. International trade has contributed also to a transition in farming systems. The change from family-owned traditional mixed systems to large-scale industryowned specialized landless animal production systems has occurred quickly, notably for monogastric animals in China (Bai et al. 2014). The specialized production systems are able to react faster to the growing demand for animal-source food. The production of pigs and poultry is also increasingly concentrating in densely populated areas and around urban centers for logistical reasons, especially in rapidly developing countries in southeast Asia (Gerber et al. 2005). This concentration contributes to the uneven spatial distributions of livestock density in many countries (Fig. 7), and to locally very high livestock densities. These specialized livestock farms have to import most or all feed from elsewhere, have insufficient land for proper manure disposal, and as a consequence have high $\mathrm{N}$ and $\mathrm{P}$ surpluses and losses to the environment (Bai et al. 2014; Strokal et al. 2016).

Spatial segregation of crop and livestock production in France has been identified as a cause of high chemical fertilizer use nationally and of high $\mathrm{P}$ surpluses in districts with livestock densities $>1.1$ LU/ha (Garnier et al. 2016; Nesme et al. 2015). Metson et al. (2016) argued that just $37 \%$ of recyclable $\mathrm{P}$ from animal manure and human wastes can meet all corn $\mathrm{P}$ demand in the USA. However, the recycled $\mathrm{P}$ sources would need to be transported on average $302 \mathrm{~km}$ to meet the largest demand in and around the center of the 'Corn Belt' region where nearly half of national corn $\mathrm{P}$ demand is located. The high costs for the proper collection, recovery and transport of manure and wastes currently prevent effective recycling (Metson et al. 2016). Obligatory transport of animal manure from areas with high livestock density to areas with low density and other countries has been implemented in The Netherlands through governmental regulations from the 1990s, at the cost of livestock producers. It has led to a lowering and regional leveling of the $\mathrm{N}$ and especially $\mathrm{P}$ surpluses (Fig. 4), and of decreased $\mathrm{N}$ and $\mathrm{P}$ losses to the environment (Van Grinsven et al. 2016). Limits to manure and fertilizer applications and emission mitigation measures are main reasons for the variations in the regression coefficients of the relations between 
livestock density and $\mathrm{N}$ and $\mathrm{P}$ balances (Fig. 8). Another reason can be that some regions are highly specialized in intensive crop production without animals but with high mineral fertilizer inputs (Garnier et al. 2016). It suggests indirectly that governmental regulations, technology and precision farming can 'correct' part of the defects in nutrient cycling when livestock production becomes landless regionally. The possibility for 'correction' are larger for $\mathrm{P}$ than for $\mathrm{N}$, mainly because of the relatively high $\mathrm{N}$ losses from animal production systems.

Though livestock production has responded to market demands largely unregulated (Steinfeld et al. 2006; Steinfeld and Gerber 2010), governments do regulate livestock density, especially in the European Union through the implementation of for example the Nitrates Directive (Velthof et al. 2014). Governmental regulations limit livestock density also in regions with very high livestock density in China (Fig. S4; Wei et al. 2016). The motivation for the regulation by governments of the intensity of livestock production was initially mainly based on environmental pollution concerns, but increasingly also on human health and odour nuisances and resources use (Steinfeld and Gerber 2010). There is a search towards sustainable production systems of animal-source food, which have to comply with basic principles, i.e. one health; customized care; no nuisance and credible performance (Scholten et al. 2013; Nijland et al. 2013). Interestingly, livestock density and limits to livestock density have as yet not been mentioned explicitly in the concept of 'careful livestock farming', suggesting that livestock density is not necessarily a main critical factor for careful livestock farming (Scholten et al. 2013). Biophysical thresholds to livestock density may follow from the need to utilize manure nutrients effectively on the farm where they are produced; this would set the threshold at 1-2 LU/ha for productive systems in temperate climate, as regulations in the European Union and especially in Denmark (Velthof et al. 2014; Asai et al. 2014). Precision feeding, emission mitigation measures, and manure processing and transport may stretch this threshold, but increases in livestock densities are met with increasing societal resistance, especially beyond $4 \mathrm{LU} / \mathrm{ha}$, as follows from the debate in The Netherlands (Scholten et al. 2013) and the expulsion of livestock farms from some urban areas in China (Fig S4; Wei et al. 2016).

\section{Conclusions}

International trade of food and feed products has strongly increased during the last five decades. Most of the trade is between a few stable exporting countries and an increasing number of importing countries. This suggests increasing specialization, which is most evident for soybean and maize, mainly because of their increasing role in feeding housed livestock.

Changes in the import of soybean and maize were linearly related to the changes in livestock density of main importing countries between 1961 and 2011. Differences in the linear regression coefficients suggest different proportions of soybean and maize in the ration of animal categories between countries. The import of soybean and maize accounted for up to $60 \%$ of the total feed demand in the selected countries.

The increased import of soybean and maize was reflected in increased $\mathrm{N}$ and $\mathrm{P}$ surpluses in the importing countries. Balances of $\mathrm{N}$ and $\mathrm{P}$ at country level were also related to livestock density; in the importing countries, the $\mathrm{N}$ balance increased 75-306 kg/ha and the $\mathrm{P}$ balance $2-49 \mathrm{~kg} / \mathrm{ha}$, when livestock density increased $1 \mathrm{LU} / \mathrm{ha}$. Changes in the export of soybean and maize were not reflected in large changes in $\mathrm{N}$ and $\mathrm{P}$ balances of the main soybean and maize exporting countries.

Livestock density within countries is spatially highly uneven. Regions with $>2$ LU/ha face environmental problems related to animal manure management and/or strict governmental regulations forcing livestock farmers to export animal manures to nearby crop farmers. Regions with $>4 \mathrm{LU} / \mathrm{ha}$ in addition meet societal objections. The results of our study contribute to the growing interest in closer spatial integration of crop and animal production, and improved manure management, also to replace synthetic fertilizers by animal manures.

Acknowledgements We thank the financial support by China Scholarship Council (CSC, Grant Number: 2011635012). Assistance from Ma Lin (Chinese Academy of Sciences) in calculation of nutrient balances in cropping systems at regional level is gratefully acknowledged.

Open Access This article is distributed under the terms of the Creative Commons Attribution 4.0 International License (http:// creativecommons.org/licenses/by/4.0/), which permits unrestricted use, distribution, and reproduction in any medium, provided you give appropriate credit to the original author(s) and 
the source, provide a link to the Creative Commons license, and indicate if changes were made.

\section{References}

Anderson K (2010) Globalization's effects on world agricultural trade, 1960-2050. Philos Trans R Soc Lond B Biol Sci 365:3007-3021

Anderson K (2014) Globalisation and agricultural trade. Aust Econ Hist Rev 54:285-306

Anglade J, Billen G, Garnier J (2015) Relationships for estimating $\mathrm{N}_{2}$ fixation in legumes: incidence for $\mathrm{N}$ balance of legume-based cropping systems in Europe. Ecosphere $6: 1-24$

Asai M, Langer V, Frederiksen P (2014) Responding to environmental regulations through collaborative arrangements: social aspects of manure partnerships in Denmark. Livest Sci 167:370-380

Bai ZH, Qin W, Chen Q et al (2014) Changes in pig production in China and their effects on nitrogen and phosphorus use and losses. Environ Sci Technol 48(21):12742-12749

Bertheau Y, Davison J (2011) Soybean in the European Union, status and perspective. In: Krezhova D (ed) Recent trends for enhancing the diversity and quality of soybean products. Intech Open Access Publisher, Rijeka, pp 3-46

Billen G, Beusen A, Bouwman L et al (2010) Anthropogenic nitrogen autotrophy and heterotrophy of the world's watersheds: past, present, and future trends. Glob Biogeochem Cycles 24:1-12

Billen G, Lassaletta L, Garnier J (2014) A biogeochemical view of the global agro-food system: nitrogen flows associated with protein production, consumption and trade. Glob Food Secur 3:209-219

Bouwman AF, Beusen AHW, Lassaletta L et al (2017) Lessons from temporal and spatial patterns in global use of $\mathrm{N}$ and $\mathrm{P}$ fertilizer on cropland. Sci Rep 7:40366

Bues A, Preißel S, Reckling M et al (2013) The environmental role of protein crops in the new common agricultural policy. In: Directorate General for Internal Policies (ed) Policy Department B: structural and cohesion policies, agriculture and rural development, Brussels, pp 1-113

CDM (2016) Advisory report on manure treatment percentages 2017. WOt-technical report 76, Wageningen University and Research, Wageningen (in Dutch)

DeFries RS, Rudel T, Uriarte M et al (2010) Deforestation driven by urban population growth and agricultural trade in the twenty-first century. Nat Geosci 3:178-181

ECCAP (2006) China animal production yearbook. China Agriculture Publishing House, Beijing (in Chinese)

Eurostat (2009) Glossary of livestock. http://ec.europa.eu/euro stat/statisticsexplained/index.php/Glossary:Livestock_ unit_(LSU). Accessed 01 May 2016

Eurostat (2016) http://ec.europa.eu/eurostat/data/database. Accessed 01 May 2016

FAOSTAT (2016) http://faostat.fao.org. Accessed May 2016

Galloway JN, Dentener FJ, Capone DG et al (2004) Nitrogen cycles: past, present, and future. Biogeochemistry 70:153-226
Garnier J, Anglade J, Benoit M et al (2016) Reconnecting crop and cattle farming to reduce nitrogen losses to river water of an intensive agricultural catchment (Seine basin, France): past, present and future. Environ Sci Policy 63:76-90

Garrett RD, Niles M, Gil J et al (2017) Policies for reintegrating crop and livestock systems: a comparative analysis. Sustainability 9(3):473

Gerber P, Chilonda P, Franceschini G et al (2005) Geographical determinants and environmental implications of livestock production intensification in Asia. Bioresour Technol 96:263-276

Hellin J, Krishna V, Erenstein O et al (2015) India's poultry revolution: implications for its sustenance and the global poultry trade. Int Food Agribus Manag Rev 18:151-164

Herridge D, Peoples M, Boddey R (2008) Global inputs of biological nitrogen fixation in agricultural systems. Plant Soil 311:1-18

Hules M, Singh S (2017) India's land grab deals in Ethiopia: food security or global politics? Land Use Policy 60:343-351

IBGE (2016) Census of agriculture 2006. Brazilian Institute for Geography and Statistics. http://www.ibge.gov.br/ estadosat/. Accessed 01 May 2016

Kastner T, Rivas MJI, Koch W et al (2012) Global changes in diets and the consequences for land requirements for food. Proc Natl Acad Sci USA 109:6868-6872

Kumar A, Singh DK (2008) Livestock production systems in India: an appraisal across agro-ecological regions. Indian J Agric Econ 63:577-597

Lassaletta L, Billen G, Grizzetti B et al (2014a) Food and feed trade as a driver in the global nitrogen cycle: 50-year trends. Biogeochemistry 118:225-241

Lassaletta L, Billen G, Grizzetti B et al (2014b) 50 Year trends in nitrogen use efficiency of world cropping systems: the relationship between yield and nitrogen input to cropland. Environ Res Lett 9:105011

Lassaletta L, Billen G, Romero E et al (2014c) How changes in diet and trade patterns have shaped the $\mathrm{N}$ cycle at the national scale: Spain (1961-2009). Reg Environ Change 14:785-797

Lassaletta L, Billen G, Garnier J et al (2016) Nitrogen use in the global food system: past trends and future trajectories of agronomic performance, pollution, trade, and dietary demand. Environ Res Lett 11:1-14

Lesschen JP, Van den Berg M, Westhoek HJ et al (2011) Greenhouse gas emission profiles of European livestock sectors. Anim Feed Sci Technol 166-167:16-28

Liu Q, Wang JM, Bai ZH et al (2017) Global animal production and nitrogen and phosphorus flows. Soil Res 55:451-462

Ma L, Ma WQ, Velthof GL et al (2010) Modeling nutrient flows in the food chain of China. J Environ Qual 39:1279-1289

Ma L, Velthof GL, Wang FH et al (2012) Nitrogen and phosphorus use efficiencies and losses in the food chain in China at regional scales in 1980 and 2005. Sci Total Environ 434:51-61

MacDonald GK, Brauman KA, Sun S et al (2015) Rethinking agricultural trade relationships in an era of globalization. Bioscience 65(3):275-289 
Metson GS, MacDonald GK, Haberman D et al (2016) Feeding the corn belt: opportunities for phosphorus recycling in U.S. agriculture. Sci Total Environ 542:1117-1126

MOA (2006) The Chinese agricultural statistical data in 2005. China Agriculture Publishing House, Beijing

Naylor R, Steinfeld H, Falcon W et al (2005) Losing the links between livestock and land. Science 310:1621-1622

NBS (2016) National Bureau of Statistics of the People's Republic of China. http://data.stats.gov.cn. Accessed 01 May 2016

Nesme T, Senthilkumar K, Mollier A et al (2015) Effects of crop and livestock segregation on phosphorus resource use: a systematic, regional analysis. Eur J Agron 71:88-95

Nijland HJ, Van Trijp HCM, Aarts MNC et al (2013) What is careful livestock farming? Substantiating the layered meaning of the term 'careful' and drawing implications for the stakeholder dialogue. NJAS Wageningen J Life Sci 66:23-31

Peyraud JL, Taboada M, Delaby L (2014) Integrated crop and livestock systems in Western Europe and South America: a review. Eur J Agron 57:31-42

R Core Team (2013) R: a language and environment for statistical computing. https://www.r-project.org/. R Foundation for Statistical Computing, Vienna, Austria

Schipanski ME, Bennett EM (2012) The influence of agricultural trade and livestock production on the global phosphorus cycle. Ecosystems 15:256-268

Schmitz C, Biewald A, Lotze-Campen H et al (2012) Trading more food: implications for land use, greenhouse gas emissions, and the food system. Glob Environ Change 22:189-209

Scholten MCT, Boer IJM, Gremmen B et al (2013) Livestock farming with care: towards sustainable production of animal-source food. NJAS Wageningen J Life Sci 66:3-5

Shiferaw B, Prasanna BM, Hellin J et al (2011) Crops that feed the world 6. Past successes and future challenges to the role played by maize in global food security. Food Secur 3:307-327

Smil V (1999) Nitrogen in crop production: an account of global flows. Glob Biogeochem Cycles 13:647-662

Steinfeld H, Gerber P (2010) Livestock production and the global environment: consume less or produce better? Proc Natl Acad Sci USA 107:18237-18238

Steinfeld H, Gerber P, Wassenaar T et al (2006) Livestock's long shadow: environmental issues and options. FAO, Rome
Strokal M, Ma L, Bai Z et al (2016) Alarming nutrient pollution of Chinese rivers as a result of agricultural transitions. Environ Res Lett 11:24014

Suweis S, Carr JA, Maritan A et al (2015) Resilience and reactivity of global food security. Proc Natl Acad Sci USA 112:6902-6907

Swamy M, Bhattacharya S (2006) Budgeting anthropogenic greenhouse gas emission from Indian livestock using country-specific emission coefficients. Curr Sci 91:1340-1353

Thornton PK (2010) Livestock production: recent trends, future prospects. Philos Trans R Soc Lond B Biol Sci 365:2853-2867

USDA (2015) USDA agricultural projections to 2024. United States Department of Agriculture 97

USDA (2016) Census of agriculture 2012. United States Department of Agriculture. https://www.agcensus. usda.gov/Publications/2012/Full_Report/Census_by_State/. Accessed 01 May 2016

Van Dijk KC, Lesschen JP, Oenema O (2016) Phosphorus flows and balances of the European Union Member States. Sci Total Environ 542:1078-1093

Van Gelder JW, Kammeraat K, Kroes H (2008) Soy consumption for feed and fuel in the European Union. A research paper prepared for Milieudefensie (Friends of the Earth Netherlands). Profundo, Castricum, The Netherlands

Van Grinsven HJM, Tiktak A, Rougoor CW (2016) Evaluation of the Dutch implementation of the nitrates directive, the water framework directive and the national emission ceilings directive. NJAS Wageningen J Life Sci 78:69-84

Velthof GL, Oudendag D, Witzke HP et al (2009) Integrated assessment of nitrogen losses from agriculture in EU-27 using MITERRA-EUROPE. J Environ Qual 38:402-417

Velthof GL, Lesschen JP, Webb J et al (2014) The impact of the nitrates directive on nitrogen emissions from agriculture in the EU-27 during 2000-2008. Sci Total Environ 468-469:1225-1233

Velthof GL, Hou Y, Oenema O (2015) Nitrogen excretion factors of livestock in the European Union: a review. J Sci Food Agric 95:3004-3014

Wei S, Bai ZH, Qin W et al (2016) Environmental, economic and social analysis of peri-urban pig production. J Clean Prod 129:596-607

Willis S (2003) The use of soybean meal and full fat soybean meal by the animal feed industry. In: 12th Australian soybean conference, pp 1-8 